\title{
Induced in vitro differentiation of neural-like cells from human exfoliated deciduous teeth-derived stem cells
}

\author{
NOSRAT NOURBAKHSH ${ }^{1}$, MITRA SOLEIMANI ${ }^{2}$, ZAHRA TAGHIPOUR ${ }^{2}$, KHADIJEH KARBALAIE $^{3}$, SEEID- \\ BEHROUZ MOUSAVI ${ }^{4}$, ARDESHIR TALEBI ${ }^{5}$, FATEMEH NADALI ${ }^{5}$, SOMAYEH TANHAEI ${ }^{3}$, GHOLAM-ABBAS \\ KIYANI ${ }^{1}$, MARZIYEH NEMATOLLAHI ${ }^{3}$, FARZANEH RABIEI ${ }^{1}$, MOHAMMAD MARDANI², HAMID BAHRAMIYAN², \\ MAHMOOD TORABINEJAD ${ }^{6}$, MOHAMMAD-HOSSEIN NASR-ESFAHANI ${ }^{3}$ and HOSSEIN BAHARVAND*,7,8

\footnotetext{
${ }^{1}$ Pediatric Department, School of Dentistry, ${ }^{2}$ Department of Anatomical Sciences, School of Medicine, Isfahan University of Medical Sciences, Isfahan, Iran, ${ }^{3}$ Department of Cell and Molecular Biology, Royan Institute for Animal Biotechnology, Isfahan, Iran, ${ }^{4}$ Endodentic Department, School of Dentistry, Torabinejad Dental Center, ${ }^{5}$ Pathology Department, Faculty of Medical Developmental Biology, Royan Institute for Stem Cell Biology and Technology, ACECR, Tehran, Iran and
} \\ Sciences, Isfahan University, Isfahan, Iran, ${ }^{6}$ Endodentic Department, Lumalinda University, U.S.A, ${ }^{7}$ Department of Stem Cells and \\ ${ }^{8}$ Department of Developmental Biology, University of Science and Culture, ACECR, Tehran, Iran.
}

\begin{abstract}
Stem cells from human exfoliated deciduous teeth (SHED) are highly proliferative, clonogenic and multipotent stem cells with a neural crest cell origin. Additionally, they can be collected with minimal invasiveness in comparison with other sources of mesenchymal stem cells (MSCs). Therefore, SHED could be a desirable option for potential therapeutic applications. In this study, SHEDs were established from enzyme-disaggregated deciduous dental pulp obtained from 6 to 9 year-old children. The cells had typical fibroblastoid morphology and expressed antigens characteristic of MSCs, STR01, CD146, CD45, CD90, CD106 and CD166, but not the hematopoietic and endothelial markers, CD34 and CD31, as assessed by FACS analysis. Differentiation assessment revealed a strong osteogenic and adipogenic potential of SHEDs. In order to further evaluate the in vitro differentiation potential of SHED into neural cells, a simple short time growth factormediated induction was used. Immunofluorescence staining and flow cytometric analysis revealed that SHED rapidly expressed nestin and $\beta$-III tubulin, and later expressed intermediate neural markers. In addition, the intensity and percentages of nestin and $\beta$-III tubulin and mature neural markers (PSA-NCAM, NeuN, Tau, TH, or GFAP) increased significantly following treatment. Moreover, RT-PCR and Western blot analyses showed that the neural markers were strongly upregulated after induction. In conclusion, these results provide evidence that SHED can differentiate into neural cells by the expression of a comprehensive set of genes and proteins that define neural-like cells in vitro. SHED cells might be considered as new candidates for the autologous transplantation of a wide variety of neurological diseases and neurotraumatic injuries.
\end{abstract}

KEY WORDS: dental pulp stem cell, Stem cells from Human Exfoliated Deciduous Teeth (SHED)

\section{Introduction}

Since the adult mammalian central nervous system (CNS) has a limited ability of regeneration after injury or disease, it has become an important target of regenerative medicine. Different strategies, including implementation of neurotrophic factors, gene therapy and cell therapy have been suggested to overcome this limited regeneration (Lindvall and Kokaia, 2010; Manfredsson et al., 2009). The growth of undifferentiated stem cells in vitro and inducing them toward the desired differentiated neural cells with subsequent cell transplantation is one important approach for cell

Abbreviations used in this paper: MSC, mesenchymal stem cell; SHED, Stem cells from Human Exfoliated Deciduous Teeth.

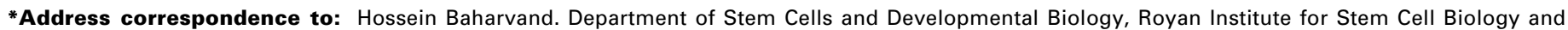

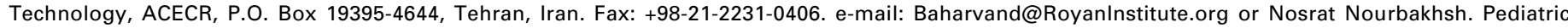
Department, School of Dentistry, Isfahan University of Medical Sciences, P.O. Box: 8174673461, Isfahan, Iran. e-mail: Nourbakhsh@dnt.mui.ac.ir
}

Supplementary Material (one figure) for this paper is available at: http://dx.doi.org/10.1387/ijdb.103090nn

Accepted: 19 August 2010. Final author corrected PDF published online: 8 June 2011.

ISSN: Online 1696-3547, Print 0214-6282 
therapy. In this regard, autologous stem cells collected from dental pulp of extracted wisdom teeth or from pulpectomy of teeth left in situ are a chance that should be improved in clinical trial. Up to now different stem/progenitor cells derived from dental tissue including dental pulp stem cells (DPSCs), stem cells from exfoliated deciduous teeth (SHED), periodontal ligament stem cells (PDLSCs), stem cells from apical papilla (SCAP), and dental follicle progenitor cells (DFPCs) (Huang et al., 2009). SHED cells are a population of highly proliferative multipotent cells capable of differentiating into functional osteoblasts, odontoblasts, endothelial cells, adipocytes, and neural cells in vitro and in vivo (Chadipiralla et al., 2010; Laino et al., 2006; Miura et al., 2003; Sakai et al., 2010). Obtaining SHED is simple and convenient, with little or no trauma. Every child loses primary teeth which creates the perfect opportunity to recover and store this convenient source of stem cells; should they be provided to treat future injuries or ailments. This presents a far better alternative to simply discarding the teeth or storing them as mementos from the past. Therefore, there are many interests in banking person-specific tooth-derived stem cells (Arora et al., 2009; Perry et al., 2008). The proliferation rate of SHED is significantly higher than that of DPSCs and BM-MSCs (Nakamura et al., 2009; Takeda et al., 2008). It is interesting to note that DPSC isolation is possible for at least five days after tooth extraction, which implies that immediate processing after extraction may not be necessary for successful DPSC banking. Further, the recovery of viable DPSCs after cryopreserving intact teeth suggests that minimal processing may be needed for the banking of samples that have no immediate plans for expansion and use (Perry et al., 2008). Even after cryopreservation these cells were capable to differentiate into neural, osteocytes/odontocytes, adipocytes, myocytes, and chondrocytes (Zhang et al., 2006) under related condition. The transplantation of these cells improved critical-size calvarial or large cranial defects in animal models (de Mendonca Costa et al., 2008; Seo et al., 2008). Additionally, the implantation of human SHED cells to golden retriever muscular dystrophy dogs showed no signs of immune rejection and presented significant engraftment and better clinical conditions (Kerkis et al., 2008). SHED transplantation is also capable of effectively reversing SLEassociated disorders in mice by increasing the ratio of regulatory T cells (Yamaza et al., 2010). It is supposed that these cells have immunosuppressive activity (Pierdomenico et al., 2005) which is so important in the field of regenerative medicine (Yalvac et al., 2009).

Therefore, based on the potentials of SHED and considering their neural crest origin, this study was undertaken to propose a simple method for SHED isolation and their differentiation into neural-like cells, as characterized by the use of a variety of experimental approaches for future transplantation in neurodegenerative diseases or neurotraumatic injuries.

\section{Results}

\section{Characteristics of isolated and in vitro expanded SHED}

After single step enzymatic treatment, viable cells with elongated shapes were detected one day after the onset of culture. These cells formed colonies upon further culture (Figs. 1A and 1B). Cells from a single colony were isolated and subcultured mechanically (first passage). Subcultured cells gradually became flattened and acquired a fibroblast-like morphology (Fig. 1C) and in this study the presented results are from one single colony. Moreover, the cultured SHEDs expressed stromal marker ALP (Fig. 1D). The ex vivo-expanded SHEDs expressed the cell surface molecules STRO-1 and CD146 (MUC18), two early MSC

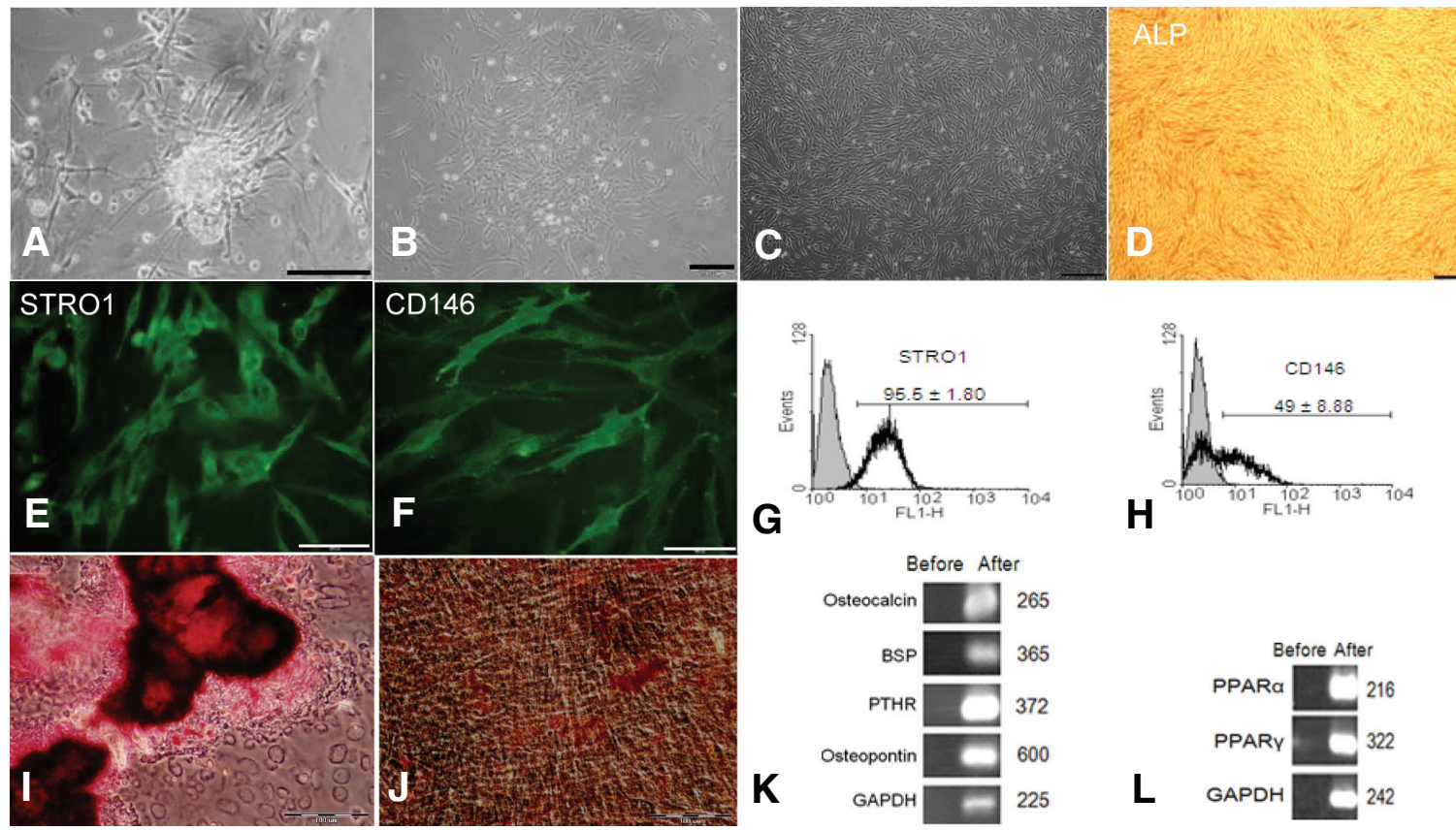

Fig. 1. Characteristics of isolated and in vitro expanded SHED. Deciduous dental pulp, 24 hours after culture (A), colony derived from SHED at the first passage (B), subconfluent culture (C), SHED cells stained for alkaline phosphatase (ALK, D), mesenchymal markers STRO-1 (E) and CD146 (F) and their corresponding flow cytometries (G,H), Oil red staining of adipogenic induced SHED (I), Alizarin red staining of osteogenic induced SHED (J), RT-PCR analysis of SHED before and after induction for adipogenesis (K), and osteogenesis (L). 


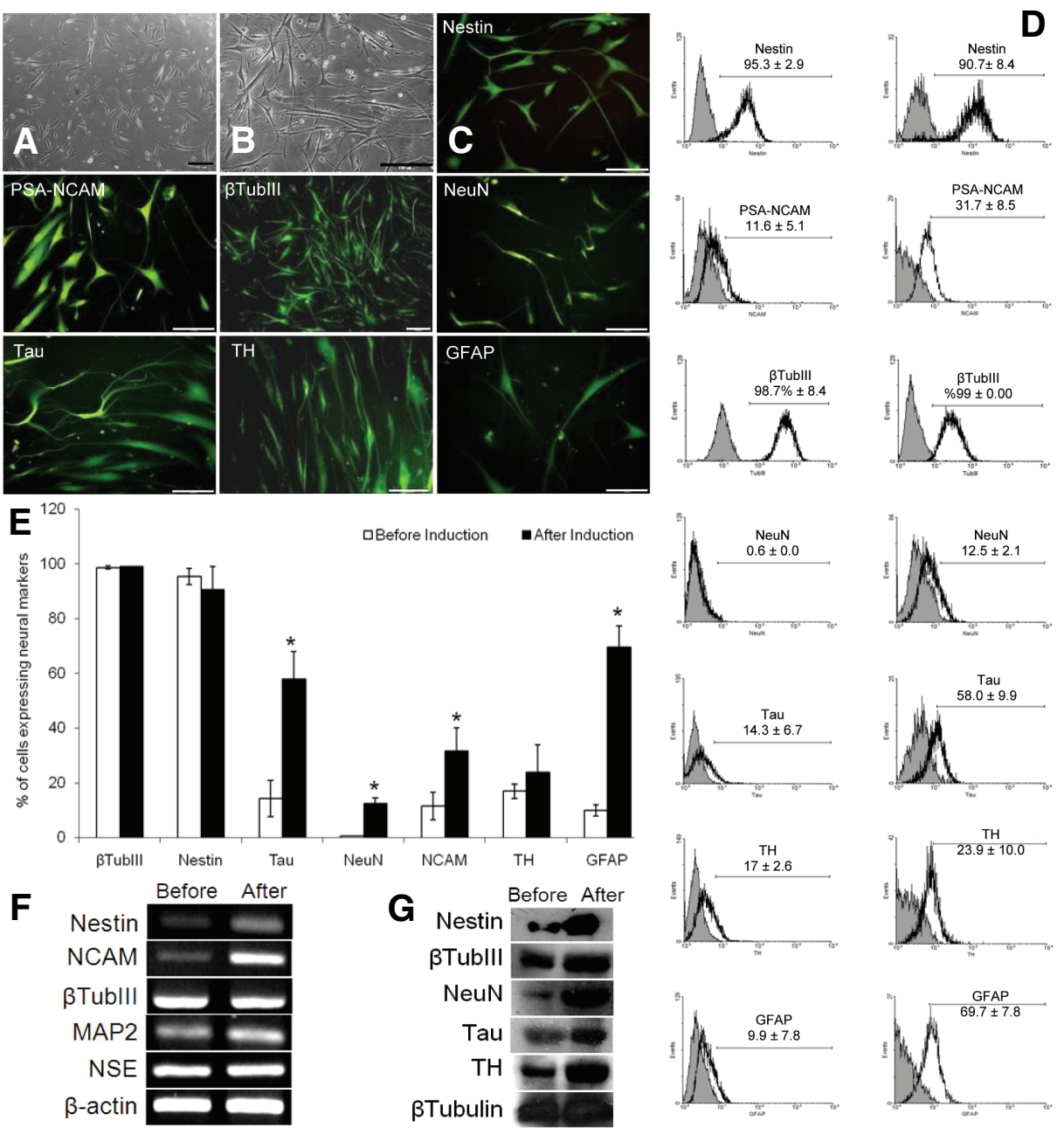

Fig. 2. Characteristics of differentiated cells. Phase contrast of SHED cells five (A) and ten (B) days after neural induction. Immunofluorescence staining for neural markers after ten days of neural induction (C). Flow cytometry histograms of neural markers assessed before and after ten days of differentiation (D). The results are summarized in Fig. E as mean $\pm S D$. Asterisks show significant difference (at least $p<0.05)$. RT-PCR (F) and Western blot (G) analyses of neural markers before and ten days after neural induction.

markers previously found to be present in bone marrow MSCs and DPSCs (Figs. 1E and 1F). Flow cytometric analysis revealed that $96.5 \pm 1.8 \%$ and $49.0 \pm 8.9 \%$ of the in vitro expanded SHEDs expressed STRO-1 and CD146, respectively (Figs.1G and $1 \mathrm{H}$ ). SHEDs positively expressed certain important MSC markers, including CD106, CD166 and CD90; while they showed a negative expression for CD31, an endothelial marker, in addition to CD34 and CD45, two hematopoietic markers (Supplementary Fig. 1).

In order to evaluate the potential of SHED cells to differentiate into mineralized cells, established secondary SHED cultures were supplemented with L-ascorbate-2-phosphate, dexamethasone, and inorganic phosphate. Alizarin red-positive nodules formed in the SHED cultures after ten days of induction (Fig. 1I), indicating calcium accumulation in vitro.

Accordingly, RT-PCR analysis revealed that various bone markers, osteocalcin, bone sialoprotein (BSP), parathyroid hormone receptor (PTHR), and osteopontin were expressed under the induction (Fig. 1K). Moreover, the cells which contained oil red positive small lipid droplets appeared three weeks after induction by dexamethasone and indomethacin (Fig. 1J). RT-PCR analysis of the induced cells showed that the transcripts of adipogenic markers, peroxisome proliferator-activated receptor- $\alpha$ (PPAR $\alpha$ ) and PPAR $\gamma$ were expressed (Fig. 1L). These data indicated that SHEDs possessed the ability to differentiate into bone and adipose cells in vitro.

\section{Neural differentiation}

We used a growth factor-mediated induction for SHED at passages 8, 14, and 18. During the induction procedure, the cytoplasm in the flat cells initially retracted towards the nucleus and formed a contracted multipolar cell body which left membranous processes much like peripheral extensions (Fig. 2A). Over the subsequent days, the cell bodies became increasingly spherical, retractile, and exhibited a typical neuronal perikaryal appearance. Gradually, SHED cell-derived neuron-like cells displayed distinct neuronal morphologies that ranged from simple bipolar to large, extensively branched multipolar cells which made connections via their processes (Fig. 2B) and saved their morphology up to day 30 . In order to verify that the observed morphological changes were not just an incipient in vitro neurogenesis which resulted from serum starvation; neural induction medium at day ten post-induction was replaced with mesenchymal medium (DMEM+10\% FCS). In this condition, the majority of cells maintained their neurallike morphology following medium exchange.

The protein expression patterns of early (nestin or PSA-NCAM), intermediate ( $\beta$-III tubulin), and late (NeuN, Tau, TH, or GFAP) neural-associated markers expressed by SHEDs cultured in the SHED and neural inductive media were shown by immunofluorescence (Fig. 2C) and flow cytometry analyses (Figs. 2D and 2E). The data revealed that SHEDs were strongly positive for nestin and $\beta$ Tublll before and after induction $(90.7 \pm 8.4 \%$ vs. $95.3 \pm 2.9 \%$ and $99.0 \pm 0.0 \%$ vs. $98.7 \pm 8.4 \%$, respectively, Figs. $2 \mathrm{D}$ and $2 \mathrm{~F})$. Of interest, these markers were highly expressed both before and after induction. The shift in the histogram of flow cytometry analysis suggested a higher intensity for both neural markers (Figs. 2D and $2 \mathrm{E})$. Moreover, a progressive enhancement in the PSA-NCAM $(31.7 \pm 8.5 \%$ vs. $11.6 \pm 5.1 \%, p<0.05)$, NeuN $(12.5 \pm 2.1 \%$ vs. $0.6 \pm 0.1 \%, p<0.002)$, tau $(58.0 \pm 9.9 \%$ vs. $14.3 \pm 6.7 \%, p<0.01), \mathrm{TH}$ $(23.9 \pm 10.0 \%$ vs. $17 \pm 2.6 \%, p<0.3)$, or GFAP $(69.7 \pm 7.8 \%$ vs. $9.9 \pm$ $7.8 \%, p<0.0001$ ) (Figs. 2D and 2E).

Supportive RT-PCR analysis demonstrated that the SHEDs expressed nestin, PSA-NCAM, $\beta$-III tubulin, MAP2, and neuron- 
specific enolase (NSE) neural markers at the mRNA level before and after culture in neural inductive media (Fig. 2F). Furthermore, western blot analysis revealed that when SHEDs were cultured in neural inductive media, the protein level of the neural markers, nestin, $\beta$-III tubulin, NeuN, tau, and TH appeared to be upregulated (Fig. 2G). Collectively, these results suggested that in response to the neural inductive stimuli, SHEDs had acquired a phenotype resembling neural-like cells.

\section{Discussion}

In this study we have investigated the neural potential of stem cells from SHED. These cells are highly proliferative MSCs, located in dental pulp and potentially derived from neural crest cells, may be an optimal source of postnatal stem cells for neural differentiation and therefore transplantation (Chai et al., 2000). Our isolated cells were colony forming and could go through more than 25 passages. We showed that SHED did not express CD34 and CD45, hematopoietic stem cell markers, and CD31, an endothelial marker, yet they expressed some important CD markers that included CD146, CD106, CD166, and CD90 (which belong to the collection of MSC CD markers) (d'Aquino et al., 2007). Additionally, in our experiment a high percentage of SHED cells expressed STRO-1, a stromal cell marker, at higher levels than previously reported by others (Miura et al., 2003) and its expression was maintained with further cell passages. These discrepancies may be attributed to cell origin, isolation procedure, passaging time, or cell-culture techniques. For example, Nagatomo et al., reported $63 \%$ STRO expression in cells derived from human periodontal ligament (Nagatomo et al., 2006). These cells presented their ability to differentiate into osteocyte-like and adipocyte-like cells after treatment with osteogenic and adipogenic induction medium as confirmed by alizarin red, oil red-O staining and RT-PCR.

Various groups have studied the potential of dental pulp cells (both adult and deciduous) to differentiate into neural, osteocytes/ odontocytes, adipocytes, myocytes, and chondrocytes under related condition (de Mendonca Costa et al., 2008; Seo et al., 2008; Stevens et al., 2008; Zhang et al., 2008). However, these researchers have mainly focused on adult rather than deciduous DPSCs or SHED. To evaluate the neuroplasticity of SHEDs, bFGF, a neural inducer was added to the SHED monolayer culture on poly-L-lysine coated dishes for five days in the absence of serum. The cells gradually lost their mesenchymal appearance and obtained a more neural appearance including neurite-like outgrowth. Further addition of SHH/FGF8 resulted in neural appearing cells with elongated and elaborated axon or dendrite-like structures. It is notable that that this neural induction procedure has not been used for the induction of such cells or SHEDs. Considering previous reports, the neural structure obtained in this procedure was more elaborate in terms of morphology and the numbers of neural extensions or axons observed (Miura et al., 2003; Morsczeck et al., 2009). Additionally, the duration of neural induction was relatively short. Furthermore, the morphology of differentiated cells did not initially change to mesenchymal cells by the replacement of differentiation medium with mesenchymal medium (data not shown) which may further confirm the neural identity of these cells, as previously stated (Bertani et al., 2005).

Further analysis of these cells by immunostaining, flow cytometry, western blot and RT-PCR analyses, revealed that neural cell markers increased upon neural induction of these cells. The differentiation of human DPSCs that have been exposed to the appropriate environmental cues into functionally active neurons has been previously reported (Arthur et al., 2008). Unlike the previous study (Miura et al., 2003), this study also presented quantitative data to support the neural properties of the induced SHED cells. The high expression of Nestin and $\beta$-Tub III in SHED cells before induction was in concordance with previous reports (Arthur et al., 2008) which may be related to the neural crest-cell origin of the dental pulp (Bronner-Fraser, 1994; Chai et al., 2000). The expression of nestin is also reported in other tissues such as the pancreas, testes, and bone marrow (Delacour et al., 2004; Yang et al., 2008), which are believed to contain multi-lineage progenitor cells with early embryonic origin (Wiese et al., 2004). However, flow cytometric analysis revealed a shift in their expression, which suggested a prominent intensity for two markers postneural induction and western blot analysis showed an increase in their expression after induction.

bFGF, SHH, and FGF8 which were used in this study have been shown to have fundamental roles in neurogenesis. Indeed, bFGF is known as a regulator of proliferation and differentiation (Dono et al., 1998) while SHH is secreted by notochord during development. $\mathrm{SHH}$ initially induces a general ventral cell fate and is required for the induction of floor plate and motor neuron differentiation (Ericson et al., 1996). FGF8, a member of the fibroblast growth factor family, is responsible for dorsalization of the anterior neural tube (Garel et al., 2003). The protocol of neural induction has already been used for dopaminergic differentiation (Kim et al., 2002). Therefore evaluation of $\mathrm{TH}$ expression, as an enzyme that only expresses at catecholamine-containing neurons, has revealed a $14 \%$ positivity of these cells for TH which increased upon neural induction to $25 \%$. This observation was further confirmed at the mRNA and protein levels and was in accordance with previous studies that showed DPSC when exposed to neurotrophic factors supported dopaminergic neurons in vitro (Nosrat et al., 2004). More recently, it was demonstrated that after incubation with a cocktail of cytokines including Shh, FGF8, glial cell line-derived neurotrophic factor, and forskolin, SHED cells differentiated into a cell population that contained specific dopaminergic neurons. Moreover, transplantation of growth factor-treated SHED cells into the striatum of parkinsonian rats partially improved the apomorphine-evoked rotation of behavioral disorders. (Wang et al., 2010).

It was demonstrated that gangliosides may play a role in the neural differentiation process of DPSCs when cultured in neurogenic medium (Ryu et al., 2009). Interestingly, a large number of regulatory genes in these differentiation interact or crosstalk via Notch, Wnt, transforming growth factor beta (TGF-beta)/bone morphogenic protein (BMP), and cadherin signaling pathways to play a crucial role in their determination (He et al., 2009; Liu et al., 2009). Moreover, it was reported that implantation of DPSCs induce endogenous axon guidance and induced neuroplasticity within a receptive host nervous system (Arthur et al., 2009).

In conclusion, we have demonstrated that stem cells derived from deciduous DPSCs are a type of MSCs that express a variety of early and intermediate neural markers in vitro. They gain neurallike morphology and significantly over-express most neural markers in an appropriate microenvironment. This neurogenic potential of SHED cells, besides their accessibility, makes them a valuable resource in clinical applications. 


\section{Materials and Methods}

\section{Isolation of dental pulp MSCs}

In this study, ten normal human exfoliated deciduous incisors were collected from six to nine year-old children under approved guidelines set by Royan Institute and the Isfahan University of Medical Sciences, Faculty of Dentistry. The pulps were gently separated from the crown and digested in a solution of $4 \mathrm{mg} / \mathrm{ml}$ collagenase type I (Invitrogen, 17100-017) containing $5 \%$ fetal calf serum (FCS, Invitrogen, 16141-079) for one hour at $37^{\circ} \mathrm{C}$. The single cells were initially cultivated in $\alpha-M E M$ medium (Sigma, M 0644) supplemented with $10 \%$ FCS in a 24-well plate (TPP, 92424). After one day, non-adherent cells were removed by washing with PBS (with $\mathrm{Ca}^{+2}$ and $\mathrm{Mg}^{+2}$, Invitrogen, 14287).

\section{Osteogenic and adipogenic differentiation}

Osteogenic and adipogenic differentiation of DPSCs were induced as previously described (Eslaminejad et al., 2006). To achieve osteogenic differentiation, cells were seeded at a density of $3 \diamond 10^{3} \mathrm{cells} / \mathrm{cm}^{2}$ and then cultured for ten days in the presence of $10 \mathrm{nM}$ dexamethasone, $50 \mu \mathrm{g} / \mathrm{ml}$ ascorbic acid 2-phosphate and $10 \mathrm{mM} \beta$-glycerophosphate. At the end of the cultivation period, the cells were fixed with $4 \%$ paraformaldehyde for 10 minutes and stained with alizarin red for 15 minutes at room temperature. This procedure allowed examination of the mineralized bone matrix.

For adipogenic differentiation, cells were grown until they reached confluence and were then induced by three cycles of induction/maintenance with $100 \mathrm{nM}$ dexamethasone and $50 \mu \mathrm{g} / \mathrm{ml}$ indomethacin. Adipogenesis was assayed by staining of intracellular lipid droplets with oil red $O$ (Sigma) as previously described (Eslaminejad et al., 2006).

\section{Alkaline phosphatase}

The SHED from each line, having been plated at $100 \mathrm{cell} / \mathrm{cm}^{2}$ in a 6-well plate, were incubated in DMEM (Invitrogen, 12800-116) supplemented with $15 \%$ ES-FCS for seven days until confluence was achieved. The cultures were then kept in an incubator at $37^{\circ} \mathrm{C}$ and $5 \% \mathrm{CO}_{2}$ for 21 days with media changes three times per week. Alkaline phosphatase (ALP) staining was performed based on the manufacturer's recommendations (Sigma, 85L3).

\section{Neural induction}

Induction of neural differentiation was initiated by plating the cells on poly-L-lysine (Sigma, P4707)-coated glass cover slips at a concentration of 5000 cells $/ \mathrm{cm}^{2}$ in neurobasal medium containing 1\% ITS (Invitrogen, 41400), and cytokines including $100 \mathrm{ng} / \mathrm{ml}$ basic fibroblast growth factor (bFGF, Sigma, F0291) for five days followed by $100 \mathrm{ng} / \mathrm{ml} \mathrm{bFGF,} 10 \mathrm{ng} / \mathrm{ml}$ FGF8 (Sigma, F6926), and $100 \mathrm{ng} / \mathrm{ml}$ sonic hedgehog (SHH, Sigma, S0191) for an additional five days. This protocol is a modified protocol that has been previously reported for neural differentiation of multipotent adult progenitor cells (MAPCs) (Jiang et al., 2003). During the first five days of induction, media were half refreshed and bFGF was added with the full concentration. Following media exchange on day five, the culture was continued without any media renewal.

\section{Flow cytometry analysis}

The passage- 4 cells from each line were harvested and the expression of cell surface markers which included: STRO1, a stromal marker and CD146, a perivascular marker, CD45, CD90, CD106 and CD166 (markers of MSCs), CD34, a hematopoietic stem cell marker, and CD31, an endothelial marker were evaluated by flow cytometry. SHEDs before and after induction were washed twice in PBS (free $\mathrm{Ca}^{+2}$ and $\mathrm{Mg}^{+2}$ ) and fixed in $4 \%$ paraformaldehyde. For permeabilization $0.2 \%$ Triton $\mathrm{X}-100$ was used. Non-specific antibody binding was blocked with the combination of $10 \%$ goat serum in primary antibodies. The primary antibodies were against the following: negative control (MCA928PE Serotec, 1:50), CD31 (MCA1738PE, Serotec, 1:50), CD90 (MCA90A647, Serotec, 1:50), CD45, (R7087, Dako, 1:100), CD34-FITC (F7166, Dako, 1:200), CD106 (MCA1557PE, Serotec, 1:50), CD166-FITC (MCA1926F, Serotec, 1:500), CD146 (MAB16985, Chemicon, 1:500), STRO-1 (MAB4315, Chemicon, 1:500), $\beta$ - Tubulin III ( $\beta$ Tublll, ab7751, Abcam, 1:200), nestin (MAB5326, Chemicon, 1:200), tau (T5530, Sigma, 1:200), neuronal nuclei (NeuN, MAB377, Chemicon, 1:200), polysialic acid-neural cell adhesion molecule (PSA-NCAM, AB5032, Chemicon, 1:200), tyrosine hydroxylase (TH, T1299, Sigma, 1:300), glial fibrillary acidic protein (GFAP, MAB3402, Millipore, 1:200) and IgG negative isotype control (CBL600, Chemicon, 1:200). The primary antibodies were incubated for 2 hours at room temperature. Binding of primary antibodies was revealed with specific secondary antisera fluorescein isothiocyanate (FITC)-conjugated antimouse IgG (AP124F, Chemicon, 1:50) for 1 hour at room temperature. Flow cytometric analysis was performed with a BD-FACS calibur flow cytometer (Becton Dickinson). The experiments were triplicated and acquired data were analyzed by using the WinMDI (2.9) software.

\section{Immunofluorescence staining}

Immunofluorescence staining was performed in cells grown on glass coverslips in relevant conditions and fixed with $4 \%$ paraformaldehyde. The following antibodies against $\beta$ TubllI, nestin, tau, NeuN, PSA-NCAM, TH, and GFAP were used for 2 hours at room temperature. Cells were washed with PBS and incubated for 1 hour, at $37^{\circ} \mathrm{C}$ with the FITC-conjugated antimouse IgG. The cells were rinsed three times with PBS and analyzed using fluorescence microscopy (Nikon, Olympus, BX51, Tokyo, Japan).

\section{Relative reverse transcription-polymerase chain reaction (RT-PCR) analysis}

Total RNA was collected from the cells induced to differentiate into neural, osteoblast and adipocyte lineages as detailed above, using the

TABLE 1

PRIMES AND THE REACTION CONDITIONS OF RT-PCR

\begin{tabular}{|c|c|c|c|c|c|}
\hline Name & Sense Primer (5'-3') & Antisense Primer (5'-3') & Accession No. & Prod. Length (bp) & Ann. $T\left({ }^{\circ} \mathrm{C}\right)$ \\
\hline Osteopontin & GCTCATTGCTCTCATCATTGGC & GGC TAA ACCCTGACCCATCTC & NM_000582.2 & 600 & 67 \\
\hline Osteocalcin & GACCATCTTTCTGCTCACTCTG & GTGATACCATAGATGCGTTTGTAG & NM_007541.2 & 275 & 65 \\
\hline $\mathrm{PTHR}^{*}$ & GACAAGCTGCTCAAGGAAGTTCTG & GGAATATCCCACGGTGTAGATCATG & NM_001083935.1 & 372 & $68 \mathrm{C}$ \\
\hline Sialoprotein & GGCAGTAGTGACCATCCGAAGAA & GGTACTGGTGCCGTTTATGCCTTG & NM_007541.2 & 359 & $68 \mathrm{C}$ \\
\hline PPAR- $\alpha$ & TGCTATCATTTGCTGTGGAG & ACTCCGTCT TCT TGATGAT & NM_001003093.1 & 216 & $68 \mathrm{C}$ \\
\hline PPAR- $\gamma$ & CTAAAGAGCCTGCGAAAG & TGTCTGTCTCCGTCTTCTTG & NM_138711.3 & 330 & $61 \mathrm{C}$ \\
\hline NCAM & TGGCAGGAGATGCCAAAGAT & CTCGGCCTTTGTGTTTCCAG & NM_000615 & 466 & $B 6$ \\
\hline$\beta$ Tub III & AGATGTACGAAGACGACGAGGAG & GTATCCCCGAAAATATAAACACAAA & NM_006086 & 313 & BO \\
\hline Nestin & CTCTGACCT GTCAGAAGAAT & СССАСТTТСТТССТСАТСТG' & NM_006617 & 172 & B2 \\
\hline MAP2 & CTGGGTCTACTGCCATCACTC & CCCCTTTAGGCTGGTATTTGA & NM_002374.3 & 282 & B6 \\
\hline NSE & CTTGGAGCTGGTGAAGGAAG & TTTTGGGTTGGTCACTGTCA & NM_001975 & 310 & 36 \\
\hline GAPDH & CAGGTGGTCTCCTCTGACTTCAAC & AGGGTCTCTCTCTTCCTCTTG & NM_002046.3 & 225 & $68 \mathrm{C}$ \\
\hline$\beta$-actin & CGTGACATTAAGGAGAAGCTGTGC & CTCAGGAGGAGCAATGATCTTGAT & NM_01101.3 & 374 & 55 \\
\hline
\end{tabular}


RNeasy Mini Kit (Qiagen, Spain). Prior to RT, RNA samples were digested with DNase I (Fermentas; EN0521) to remove contaminating genomic DNA. Standard RT was performed using $2 \mu \mathrm{g}$ total RNA, oligo (dT) and the RevertAid $^{\mathrm{TM}}$ Minus First Strand cDNA Synthesis Kit (Fermentas; K1622) according to the manufacturer's instructions. The cDNA samples were subjected to PCR amplification using primers (Table 1). The PCR products were analyzed by gel electrophoresis on a $1.7 \%$ agarose gel and stained with ethidium bromide $(0.5 \mu \mathrm{g} / \mathrm{ml})$ and visualized and photographed on a UV transilluminator (SynGene, UK).

\section{Western blotting}

Western blot analysis was carried out as previously described (Henkel and Bieger, 1994; Nasrabadi et al., 2009). Briefly, cell pellets were treated with $10 \%(\mathrm{w} / \mathrm{v})$ trichloroacetic acid in acetone with $0.07 \%(\mathrm{w} / \mathrm{v})$ dithiothreitol (DTT) at $-20^{\circ} \mathrm{C}$ for 1 hour. The suspension was centrifuged for 15 minutes at $16000 \mathrm{~g}$. The pellets were washed with ice-cold acetone, incubated at $-20^{\circ} \mathrm{C}$ for 30 minutes and centrifuged again at $4^{\circ} \mathrm{C}$ at $12000 \mathrm{~g}$ for 15 minutes. The pellets were lyophilized. The sample powder was then solubilized in lysis buffer [9.5 M urea, $2 \%(w / v)$ CHAPS, $0.8 \%(w / v)$ pharmalyte $\mathrm{pH} 3-10,1 \%(\mathrm{w} / \mathrm{v}) \mathrm{DTT}]$ and protein concentration was assessed by the Bradford assay (Bio-Rad) using BSA as the standard. The prepared samples were electrophoresed under reducing conditions on $10 \%$ SDS-PAGE gels (Bio-Rad, Munich, Germany) and then transferred to PVDF membranes (Bio-Rad, Munich, Germany). Page ruler prestained protein ladder (SM 0671; Fermentas, Germany) was applied for the evaluation of molecular weights. Membranes were blocked overnight in $10 \%$ skim milk (Merck, Germany) in PBS and incubated with primary different antibodies including $\beta$ TubllI (1:200), nestin (1:200), TH (1:200), NeuN (1:200), tau (1:200) and $\beta$-Tubulin (T5293, Sigma-Aldrich, $1: 200$, housekeeping gene or internal control), for 90 minutes. The blots were washed once for 15 minutes and then 3 times, each time for 5 minutes using tris buffer that contained $0.05 \%$ Tween 20 (Sigma, USA). For detection of primary antibodies blots were incubated with the appropriate horseradish peroxidase (HRP, Dako P0447) conjugated secondary antibodies for 1 hour. The washing procedure was repeated and bound secondary antibodies were detected using ECL advanced western blotting detection (GE Healthcare) and visualized by x-ray films (Agfa, Mortsel, Belgium)

\section{Statistical analysis}

The experiments were repeated at least three times and the values expressed as mean \pm SD. One-way ANOVA followed by the Tukey post hoc test multiple group comparison was used to analyze group differences of the data collected from flow cytometric analysis. The difference between groups was then considered to be statistically reliable if a value of $p<0.05$ was obtained.

\section{Acknowledgements \\ This study was supported by a grant from Royan Institute, Tehran,} Iran.

\section{References}

ARORA, V., ARORA, P. and MUNSHI, A.K. (2009). Banking stem cells from human exfoliated deciduous teeth (SHED): saving for the future. J Clin Pediatr Dent 33: 289-294.

ARTHUR, A., RYCHKOV, G., SHI, S., KOBLAR, S.A. and GRONTHOS, S. (2008). Adult human dental pulp stem cells differentiate toward functionally active neurons under appropriate environmental cues. Stem Cells 26: 1787-1795.

ARTHUR, A., SHI, S., ZANNETTINO, A.C., FUJII, N., GRONTHOS, S. and KOBLAR, S.A. (2009). Implanted adult human dental pulp stem cells induce endogenous axon guidance. Stem Cells 27: 2229-2237.

BERTANI, N., MALATESTA, P., VOLPI, G., SONEGO, P. and PERRIS, R. (2005) Neurogenic potential of human mesenchymal stem cells revisited: analysis by immunostaining, time-lapse video and microarray. J Cell Sci 118: 3925-3936.
BRONNER-FRASER, M. (1994). Neural crest cell formation and migration in the developing embryo. FASEB J 8: 699-706.

CHADIPIRALLA, K., YOCHIM, J.M., BAHULEYAN, B., HUANG, C.Y., GARCIAGODOY, F., MURRAY, P.E. and STELNICKI, E.J. Osteogenic differentiation of stem cells derived from human periodontal ligaments and pulp of human exfoliated deciduous teeth. Cell Tissue Res 340: 323-333.

CHAI, Y., JIANG, X., ITO, Y., BRINGAS, P., JR., HAN, J., ROWITCH, D.H., SORIANO, P., MCMAHON, A.P. and SUCOV, H.M. (2000). Fate of the mammalian cranial neural crest during tooth and mandibular morphogenesis. Development 127: 1671-1679.

D'AQUINO, R., GRAZIANO, A., SAMPAOLESI, M., LAINO, G., PIROZZI, G., DE ROSA, A. and PAPACCIO, G. (2007). Human postnatal dental pulp cells codifferentiate into osteoblasts and endotheliocytes: a pivotal synergy leading to adult bone tissue formation. Cell Death Differ 14: 1162-1171.

DE MENDONCA COSTA, A., BUENO, D.F., MARTINS, M.T., KERKIS, I., KERKIS A., FANGANIELLO, R.D., CERRUTI, H., ALONSO, N. and PASSOS-BUENO, M.R. (2008). Reconstruction of large cranial defects in nonimmunosuppressed experimental design with human dental pulp stem cells. J Craniofac Surg 19: 204-210.

DELACOUR, A., NEPOTE, V., TRUMPP, A. and HERRERA, P.L. (2004). Nestin expression in pancreatic exocrine cell lineages. Mech Dev 121: 3-14.

DONO, R., TEXIDO, G., DUSSEL, R., EHMKE, H. and ZELLER, R. (1998). Impaired cerebral cortex development and blood pressure regulation in FGF-2 deficient mice. EMBO J 17: 4213-4225

ERICSON, J., MORTON, S., KAWAKAMI, A., ROELINK, H. and JESSELL, T.M (1996). Two critical periods of Sonic Hedgehog signaling required for the specification of motor neuron identity. Cell 87: 661-673.

ESLAMINEJAD, M.B., NIKMAHZAR, A., TAGHIYAR, L., NADRI, S. and MASSUMI, M. (2006). Murine mesenchymal stem cells isolated by low density primary culture system. Dev Growth Differ 48: 361-370.

GAREL, S., HUFFMAN, K.J. and RUBENSTEIN, J.L. (2003). Molecular regionalization of the neocortex is disrupted in Fgf8 hypomorphic mutants. Development 130: 1903-14.

HE, F., YANG, Z., TAN, Y., YU, N., WANG, X., YAO, N. and ZHAO, J. (2009). Effects of Notch ligand Delta1 on the proliferation and differentiation of human dental pulp stem cells in vitro. Arch Oral Biol 54: 216-222.

HENKEL, A.W. and BIEGER, S.C. (1994). Quantification of proteins dissolved in an electrophoresis sample buffer. Anal Biochem 223: 329-331.

HUANG, G.T., GRONTHOS, S. and SHI, S. (2009). Mesenchymal stem cells derived from dental tissues vs. those from other sources: their biology and role in regenerative medicine. J Dent Res 88: 792-806.

JIANG, Y., HENDERSON, D., BLACKSTAD, M., CHEN, A., MILLER, R.F. and VERFAILLIE, C.M. (2003). Neuroectodermal differentiation from mouse multipotent adult progenitor cells. Proc Natl Acad Sci USA 100 Suppl 1: 1185411860

KERKIS, I., AMBROSIO, C.E., KERKIS, A., MARTINS, D.S., ZUCCONI, E., FONSECA, S.A., CABRAL, R.M., MARANDUBA, C.M., GAIAD, T.P., MORINI, A.C. et al. (2008). Early transplantation of human immature dental pulp stem cells from baby teeth to golden retriever muscular dystrophy (GRMD) dogs: Local or systemic? J Trans/ Med 6: 35.

KIM, J.H., AUERBACH, J.M., RODRIGUEZ-GOMEZ, J.A., VELASCO, I., GAVIN, D., LUMELSKY, N., LEE, S.H., NGUYEN, J., SANCHEZ-PERNAUTE, R., BANKIEWICZ, K. et al. (2002). Dopamine neurons derived from embryonic stem cells function in an animal model of Parkinson's disease. Nature 418: 50 56.

LAINO, G., CARINCI, F., GRAZIANO, A., D'AQUINO, R., LANZA, V., DE ROSA, A., GOMBOS, F., CARUSO, F., GUIDA, L., RULLO, R. et al. (2006). In vitro bone production using stem cells derived from human dental pulp. J Craniofac Surg 17: $511-515$

LINDVALL, O. and KOKAIA, Z. (2010). Stem cells in human neurodegenerative disorders-time for clinical translation? J Clin Invest 120: 29-40.

LIU, L., LING, J., WEI, X., WU, L. and XIAO, Y. (2009). Stem cell regulatory gene expression in human adult dental pulp and periodontal ligament cells undergoing odontogenic/osteogenic differentiation. J Endod 35: 1368-1376.

MANFREDSSON, F.P., OKUN, M.S. and MANDEL, R.J. (2009). Gene therapy for neurological disorders: challenges and future prospects for the use of growth 
factors for the treatment of Parkinson's disease. Curr Gene Ther 9: 375-388.

MIURA, M., GRONTHOS, S., ZHAO, M., LU, B., FISHER, L.W., ROBEY, P.G. and SHI, S. (2003). SHED: stem cells from human exfoliated deciduous teeth. Proc Natl Acad Sci USA 100: 5807-5812.

MORSCZECK, C., VOLLNER, F., SAUGSPIER, M., BRANDL, C., REICHERT, T.E., DRIEMEL, O. and SCHMALZ, G. (2010). Comparison of human dental follicle cells (DFCs) and stem cells from human exfoliated deciduous teeth (SHED) after neural differentiation in vitro. Clin Oral Investig 14: 433-440.

NAGATOMO, K., KOMAKI, M., SEKIYA, I., SAKAGUCHI, Y., NOGUCHI, K., ODA, S., MUNETA, T. and ISHIKAWA, I. (2006). Stem cell properties of human periodontal ligament cells. J Periodontal Res 41: 303-310.

NAKAMURA, S., YAMADA, Y., KATAGIRI, W., SUGITO, T., ITO, K. and UEDA, M. (2009). Stem cell proliferation pathways comparison between human exfoliated deciduous teeth and dental pulp stem cells by gene expression profile from promising dental pulp. J Endod 35: 1536-1542.

NASRABADI, D., REZAEI LARIJANI, M., PIRHAJI, L., GOURABI, H., SHAHVERDI, A., BAHARVAND, H. and SALEKDEH, G.H. (2009). Proteomic analysis of monkey embryonic stem cell during differentiation. J Proteome Res 8: 15271539.

NOSRAT, I.V., SMITH, C.A., MULLALLY, P., OLSON, L. and NOSRAT, C.A. (2004). Dental pulp cells provide neurotrophic support for dopaminergic neurons and differentiate into neurons in vitro; implications for tissue engineering and repair in the nervous system. Eur J Neurosci 19: 2388-2398.

PERRY, B.C., ZHOU, D., WU, X., YANG, F.C., BYERS, M.A., CHU, T.M., HOCKEMA, J.J., WOODS, E.J. and GOEBEL, W.S. (2008). Collection, cryopreservation, and characterization of human dental pulp-derived mesenchymal stem cells for banking and clinical use. Tissue Eng Part C Methods 14: 149-156.

PIERDOMENICO, L., BONSI, L., CALVITTI, M., RONDELLI, D., ARPINATI, M., CHIRUMBOLO, G., BECCHETTI, E., MARCHIONNI, C., ALVIANO, F., FOSSATI, V. et al. (2005). Multipotent mesenchymal stem cells with immunosuppressive activity can be easily isolated from dental pulp. Transplantation 80: 836-842.

RYU, J.S., KO, K., LEE, J.W., PARK, S.B., BYUN, S.J., JEONG, E.J., KO, K. and CHOO, Y.K. (2009). Gangliosides are involved in neural differentiation of human dental pulp-derived stem cells. Biochem Biophys Res Commun 387: 266-271.

SAKAI, V.T., ZHANG, Z., DONG, Z., NEIVA, K.G., MACHADO, M.A., SHI, S. SANTOS, C.F. and NOR, J.E. (2010). SHED Differentiate into Functional
Odontoblasts and Endothelium. J Dent Res 89: 791-796.

SEO, B.M., SONOYAMA, W., YAMAZA, T., COPPE, C., KIKUIRI, T., AKIYAMA, K. LEE, J.S. and SHI, S. (2008). SHED repair critical-size calvarial defects in mice. Oral Dis 14: 428-434.

STEVENS, A., ZULIANI, T., OLEJNIK, C., LEROY, H., OBRIOT, H., KERRCONTE, J., FORMSTECHER, P., BAILLIEZ, Y. and POLAKOWSKA, R.R (2008). Human dental pulp stem cells differentiate into neural crest-derived melanocytes and have label-retaining and sphere-forming abilities. Stem Cells Dev 17: 1175-1184.

TAKEDA, T., TEZUKA, Y., HORIUCHI, M., HOSONO, K., IIDA, K., HATAKEYAMA, D., MIYAKI, S., KUNISADA, T., SHIBATA, T. and TEZUKA, K. (2008). Characterization of dental pulp stem cells of human tooth germs. J Dent Res 87: 676681.

WANG, J., WANG, X., SUN, Z., WANG, X., YANG, H., SHI, S. and WANG, S. (2010). Stem Cells from Human Exfoliated Deciduous Teeth Can Differentiate into Dopaminergic Neuron-like Cells. Stem Cells Dev 19: 1375-1383.

WIESE, C., ROLLETSCHEK, A., KANIA, G., BLYSZCZUK, P., TARASOV, K.V., TARASOVA, Y., WERSTO, R.P., BOHELER, K.R. and WOBUS, A.M. (2004) Nestin expression-a property of multi-lineage progenitor cells? Cell Mol Life Sci 61: 2510-2522.

YALVAC, M.E., RIZVANOV, A.A., KILIC, E., SAHIN, F., MUKHAMEDYAROV, M.A., ISLAMOV, R.R. and PALOTAS, A. (2009). Potential role of dental stem cells in the cellular therapy of cerebral ischemia. Curr Pharm Des 15: 39083916.

YAMAZA, T., KENTARO, A., CHEN, C., LIU, Y., SHI, Y., GRONTHOS, S., WANG, S. and SHI, S. (2010). Immunomodulatory properties of stem cells from human exfoliated deciduous teeth. Stem Cell Res Ther 1: 5.

YANG, X.H., WU, Q.L., YU, X.B., XU, C.X., MA, B.F., ZHANG, X.M., LI, S.N., LAHN, B.T. and XIANG, A.P. (2008). Nestin expression in different tumours and its relevance to malignant grade. J Clin Pathol 61: 467-473.

ZHANG, W., WALBOOMERS, X.F., SHI, S., FAN, M. and JANSEN, J.A. (2006) Multilineage differentiation potential of stem cells derived from human dental pulp after cryopreservation. Tissue Eng 12: 2813-2823.

ZHANG, W., WALBOOMERS, X.F., VAN KUPPEVELT, T.H., DAAMEN, W.F., VAN DAMME, P.A., BIAN, Z. and JANSEN, J.A. (2008). In vivo evaluation of human dental pulp stem cells differentiated towards multiple lineages. J Tissue Eng Regen Med 2: 117-125. 


\section{Further Related Reading, published previously in the Int. J. Dev. Biol.}

Role of TGF beta and myofibroblasts in supporting the propagation of human embryonic stem cells in vitro Neeraj Kumar, Prasad Pethe and Deepa Bhartiya

Int. J. Dev. Biol. (2010) 54: 1329-1336 (doi: 10.1387/ijdb.092854nk)

Induction of neural crest cells from mouse embryonic stem cells in a serum-free monolayer culture

Yuko Aihara, Yohei Hayashi, Mitsuhi Hirata, Nobutaka Ariki, Shinsuke Shibata, Narihito Nagoshi, Mio Nakanishi, Kiyoshi Ohnuma, Masaki Warashina, Tatsuo Michiue, Hideho Uchiyama, Hideyuki Okano, Makoto Asashima and Miho Kusuda Furue

Int. J. Dev. Biol. (2010) 54: 1287-1294 (doi: 10.1387/ijdb.103173ya)

Hematopoietic stem cell emergence in the conceptus and the role of Runx1

Gemma Swiers, Marella de Bruijn and Nancy A. Speck

Int. J. Dev. Biol. (2010) 54: 1151-1163

Allantois and placenta as developmental sources of hematopoietic stem cells

Françoise Dieterlen-Lièvre, Catherine Corbel and Josselyne Salaün

Int. J. Dev. Biol. (2010) 54: 1079-1087

Dissecting hematopoietic differentiation using the embryonic stem cell differentiation model

Tara L. Huber

Int. J. Dev. Biol. (2010) 54: 991-1002

Challenges and strategies for generating therapeutic patient-specific hemangioblasts and hematopoietic stem cells from human pluripotent stem cells

Ann Peters, Paul W. Burridge, Marina V. Pryzhkova, Michal A. Levine,Tea-Soon Park, Christopher Roxbury, Xuan Yuan, Bruno Péault and Elias T. Zambidis Int. J. Dev. Biol. (2010) 54: 965-990

Novel roles for Notch, Wnt and Hedgehog in hematopoesis derived from human pluripotent stem cells

Chantal Cerdan and Mickie Bhatia

Int. J. Dev. Biol. (2010) 54: 955-963

Feeder- and serum-free establishment and expansion of human induced pluripotent stem cells

Mehdi Totonchi, Adeleh Taei, Ali Seifinejad, Mohammadsharif Tabebordbar, Hassan Rassouli, Ali Farrokhi, Hamid Gourabi, Nasser Aghdami, Ghasem Hosseini-Salekdeh and Hossein Baharvand

Int. J. Dev. Biol. (2010) 54: 877-886

On the origin of amniotic stem cells: of mice and men

Mariya P. Dobreva, Paulo N.G. Pereira, Jan Deprest and An Zwijsen

Int. J. Dev. Biol. (2010) 54: 761-777

Characterization of mouse embryonic stem cell differentiation into the pancreatic lineage in vitro by transcriptional profiling, quantitative RT-PCR and immunocytochemistry

Alexandra Rolletschek, Insa S. Schroeder, Herbert Schulz, Oliver Hummel, Norbert Huebner and Anna M. Wobus

Int. J. Dev. Biol. (2010) 54: 41-54 Int. J. Dev. Biol. (2007) 51: 327-331

5 yr ISI Impact Factor (2009) $=3.253$

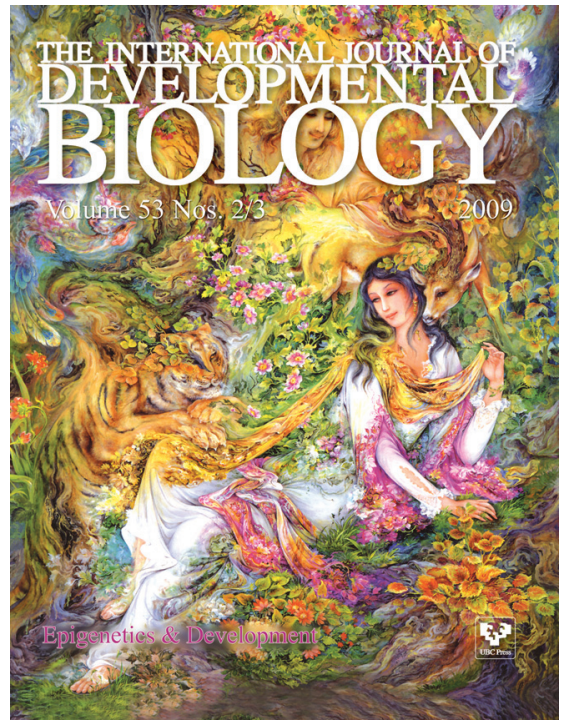

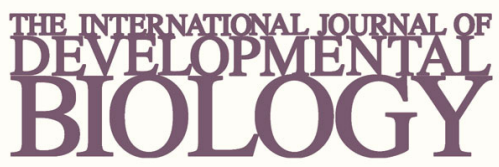

Volume 54 Nos. $6 / 7$
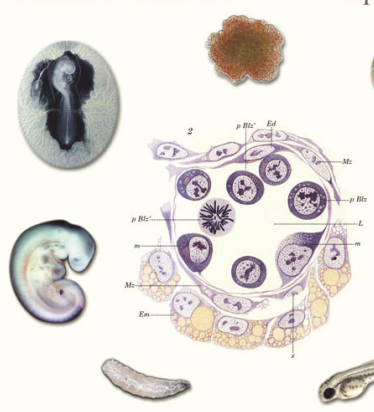

Developmental Hematopoiesis
Special Issue

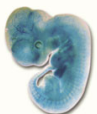

(
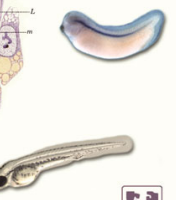

Ward

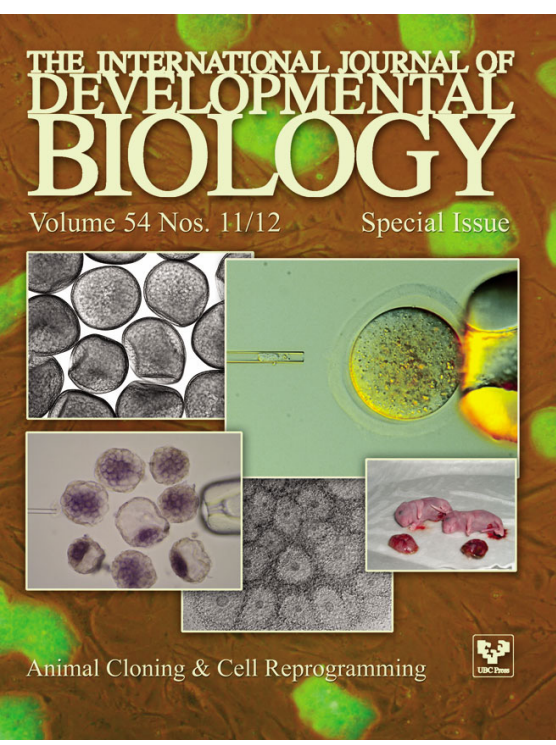

